\title{
Wonder-making and Philosophical Wonder in Hero of Alexandria
}

Tybjerg, Karin

Published in:

Studies in History and Philosophy of Science - Part A

Publication date:

2003

Document license:

Unspecified

Citation for published version (APA):

Tybjerg, K. (2003). Wonder-making and Philosophical Wonder in Hero of Alexandria. Studies in History and Philosophy of Science - Part A, 34, 443-466. 


\title{
Wonder-making and philosophical wonder in Hero of Alexandria
}

\author{
Karin Tybjerg \\ University of Cambridge, Darwin College, Cambridge CB3 9EU, UK
}

Received 12 February 2002; received in revised form 16 December 2002

\begin{abstract}
In his treatises Hero of Alexandria describes a range of devices for producing spectacles and generating wonder that have frequently been treated as marginal by historians of technology and science. In this paper I shall show that these devices and Hero's emphasis on wonder-making are of central importance to the image that Hero presents of mechanics. Hero uses the concept of wonder to add an intellectual component to the utility of mechanics, to strengthen the epistemological claims of mechanics and to relate mechanical expertise to divine cunning. He is thereby able to present mechanics as a form of knowledge which is epistemically on a par with philosophy, but which still maintains powerful practical consequence.

(C) 2003 Published by Elsevier Ltd.
\end{abstract}

Keywords: Hero of Alexandria; Wonder; Automata; Ancient Mechanics; Ancient Science

In ancient Greek writers on mechanics we find an extraordinary number of devices designed to create wonder and surprise in an audience. There are reports that Archytas of Tarentum, as early as the fourth century BC, constructed a flying mechanical dove, and in the second century Ctesibius and Philo wrote on water-organs, water clocks and automata. ${ }^{1}$ The most prolific writer known on mechanical devices is Hero

E-mail address: kt206@cam.ac.uk (K. Tybjerg).

${ }^{1}$ The reference to Archytas' dove is in Aulus Gellius, 10.12.9f. For devices in Ctesibius, Philo and Hero, see for example Brumbaugh (1966), Drachmann (1948), and Schürmann (1991). 
of Alexandria, who flourished in the first century AD. ${ }^{2}$ His work covers a diversity of mechanical and geometrical topics, ranging from geometry, land measurement and catapult construction, to lifting machines, pneumatic devices, and automatic theatres. ${ }^{3}$ Many of his devices are explicitly aimed at exciting wonder. They include, for instance, an automatic theatre featuring thunder and burning fire, and a mirror that shows a goddess rather than a reflection of the viewer. ${ }^{4}$ In this paper I shall show that such devices play a central role for the image that Hero presents of mechanical knowledge.

Historians of technology have often marginalized devices aimed at wonder-making in favour of devices presumed to have more direct practical applications. The technologies that have attracted most of their attention were those that fitted into modern categories, such as civil or hydraulic engineering. Since devices for wonder-making do not sit comfortably with such categories, they were often categorized as "toys" or as a spare-time occupation of mechanical writers..$^{5}$ Moreover, many historians of technology have focused on evaluating technological progress, mainly in terms of increased productivity in farming, mining, construction, transport and warfare. ${ }^{6}$ This rather narrow interpretation of technology and its uses creates an artificial divide between devices that are described side by side in Hero's treatises, and thus precludes

\footnotetext{
2 The best dating of Hero is based on a passage in the Dioptra where Hero estimates the distance between Rome and Alexandria using an eclipse of the moon as point of reference. From Hero's data Neugebauer (1938) identified the eclipse as one that took place in AD 64. See also the discussion of the problem of Hero's dates in Drachmann (1948).

${ }^{3}$ Of Hero's works the Pneumatics, Automata-construction, Metrica, Dioptra and Artillery-construction are extant in the original Greek. The Mechanics is preserved in an Arabic translation and Catoptrics in a Latin abbreviation. The latter was earlier ascribed to Ptolemy, but was attributed to Hero when Ptolemy's Optics was found in an Arabic translation, see Schmidt \& Nix (1900), pp. 303-315. The attribution to Hero was later doubted by Jones (2001), but it can under all circumstances be regarded as a work from Hero's school. Lastly there are the Geometry, Stereometry and Definitions, which are textually difficult and of dubious attribution. I shall refer to Hero's treatises in the Teubner edition, Schmidt et al. (18991914), except for the Artillery-construction, which is edited in Marsden (1971). Unless otherwise stated, all translations from Hero are my own.

4 Pneumatics, 322.8-328.14; and Automata-construction, e.g. 414.12-23.

${ }^{5}$ Green (1990), p. 478, dismissed all the work of Hero and other mechanical writers as 'a collection of elaborate mechanical toys, curiosities, the subsidized exotica of an authoritarian regime'. Scholars writing on technology were not quite as condemning, but viewed Hero's devices for entertainment as a sideline. White (1984), p. 181, and Brumbaugh (1966), p. 94, considered it a spare time occupation. Gille (1957), p. 633, called them 'useless scientific toys', while Landels (1978), p. 202, more diplomatically, wrote that these devices were 'ornamental and entertaining, rather than useful'. Lastly, Hill (1984, pp. 199-200), considered the automata important, but this was mainly because many of the ideas found in automata later entered the vocabulary of mechanical technology. For a more balanced account, see Schürmann (1991).

${ }^{6}$ Finley (1959) linked the development of technology to productivity and economic activity. Other examples of accounts that discuss why ancient technology did not lead to increased productivity are: Brunet and Miele (1935); Klemm (1954); Vernant (1957); Pleket (1967,1973); Kiechle (1969); Reece (1969); Lee (1973); and lastly Wikander (1984), who went against the stream and claimed that technology was employed to increase productivity.
} 
understanding of Hero's own presentation of mechanical knowledge. ${ }^{7}$ Isolating a group of devices as "toys" obscures the importance of these devices and of wondermaking in general for the self-definition of mechanics.

The role of wonders and marvels in the development of science has recently been explored in the Middle Ages and Early Modern period. ${ }^{8}$ The concept of wonder, however, also played an important role in ancient Greece and Rome, in philosophy as well as in technical disciplines, and this material has only been drawn into the debates of later periods to a limited degree. With this paper I wish to contribute to the discussion of the relationship between wonder, science and technology by dealing with the role of wonder in Hero of Alexandria's presentation of mechanical knowledge. In the process I hope to widen our notion of the aims of mechanics in antiquity and to provide some background for understanding wonder-making in later periods.

My analysis concentrates on the treatises in which Hero refers explicitly to wonder-making. Especially relevant are the Pneumatics, the Catoptrics, and the Automaton-construction. The Pneumatics describes an array of hydraulic devices (such as automata, wine mixers and pumps) and discusses the physical properties of air; the Catoptrics concerns reflection in mirrors and the construction of novelty mirrors for use at private shows and temples; and the Automaton-construction describes two automatic theatres and their 'shows'. These treatises are all organized with an introductory section presenting and justifying the subject of the treatise, and a longer main section describing a selection of devices. I shall consider the introductions to these treatises and show how Hero integrates wonder-making into mechanics, as well as discuss how the devices described in the main parts of the treatises support Hero's claims for the utility and demonstrative power of mechanics.

I shall show that the concept of wonder plays a pivotal role in Hero's promotion of mechanics as a form of knowledge that is elevated above manual work and that holds a epistemological status on a par with-or even superior to-that of philosophy. At the same time I hope to make clear that Hero's mechanical treatises cannot be understood simply as descriptions of the technology of his period and evaluated as such. Hero's mechanics should also be understood as a field of knowledge that was related to and competitive with philosophical writings and rhetorical displays. I shall offer three areas where the concept of wonder helps Hero create an image of mechanics as a powerful and independent form of knowledge. First, I show how Hero employs the concept of wonder to redefine 'useful' knowledge relative to the negative accounts given by certain philosophers; second I consider how the ability to generate and control spectacles underscores Hero's claim that he provides better demonstrations of his physical theories than philosophers can of theirs; and last I discuss how Hero plays on the relationship between mechanics, craftsmanship and mythology and thereby associates mechanical expertise with divine craftsmanship.

\footnotetext{
7 Drachmann (1948) argued that the Pneumatics was a private collection of descriptions that had not yet been prepared for publication. This argument does not, however, change the fact that Hero viewed all this material as belonging to one subject, namely pneumatics.

${ }^{8}$ The most notable treatment of the concept of wonder in science is Daston \& Park (1998), which spans the period 1150-1750.
} 


\section{Wonder and utility}

Hero presents useful knowledge. He states explicitly in many of his treatises that his subject matter is useful and he gives ostensibly practical instructions on how to construct mechanical devices. ${ }^{9}$ It is therefore necessary to consider some of the attitudes confronting Hero when he justifies his material as useful. For instance, many earlier and contemporary philosophical writers regarded useful knowledge as a lower from of knowledge. Plato is the obvious example, ${ }^{10}$ but Aristotle also downgrades utility and Aristotle is especially relevant in the case of Hero, because Aristotelian philosophy appears to have had a strong presence in Alexandria. Although this is primarily documented earlier than Hero, in the fourth and third centuries $\mathrm{BC},{ }^{11}$ Hero appears to have worked in an environment where Aristotelianism was well known, for he refers to Aristotle and was influenced by Strato, Aristotle's successor at the Lyceum. $^{12}$

In the opening to the Metaphysics Aristotle establishes a hierarchy of knowledge where perception is placed as the lowest form of cognition and philosophy as the highest. The arts (technai) come in between. Aristotle describes the development of the arts as follows:

At first he who invented any art (technê) that went beyond the common perceptions was naturally wondered (thaumazo) at by men, not only because there was something useful (chrêsimos) in the inventions, but because he was thought wise and superior to the rest. But as more arts were invented, and some were directed to the necessities of life (anankaia), others to its recreation, the inventors of the latter were always regarded as wiser than the inventors of the former, because their branches of knowledge did not aim at utility (chrêsis). Hence when all such inventions were already established, the sciences which do not aim at giving pleasure or aim at the necessities of life (anankaia) were discovered, and first in the places where men first began to have leisure. ${ }^{13}$

According to this story, it was the 'wisdom' of the inventors and not the practical uses that were admired and wondered at about the 'arts'; and the further away a given 'art' was removed from uses and necessities, the wiser its inventors were

\footnotetext{
${ }^{9}$ Hero comments on the utility of mechanics at: Metrica, 4.4-7; Dioptra, 188.3-7, 190.1; Artilleryconstruction, 73.8 and 74.3; Pneumatics, 2.18-20; Catoptrics, 318.22; and Mechanics, III.1.

${ }_{10}$ Plato contrasts manual arts and the search for truth (philosophy), for example, in Philebus, 58Bff.

11 See von Staden (1989), pp. 39 and 97, on the presence of Aristotelian philosophy in the Hellenistic period.

${ }^{12}$ Hero refers to Aristotle in the Catoptrics, 318.7. The extent to which Hero draws on Strato in the introduction to the Pneumatics is widely debated: see Diels (1893); Furley (1989); Berryman (1997); and Lehoux (1999). I argue in Tybjerg (2000) that Hero did draw on Strato, but that the evidence for the extent of this influence is inconclusive; Hero's text can under no circumstances be understood as being copied from a single source.

13 Aristotle, Metaphysics, 981b14ff. Text in Ross (1958) and translation by Ross in Barnes (1984) with my modifications.
} 
thought to be. Thus, utility is presented by Aristotle as detracting status from the practitioner of an 'art' rather than adding to it. Further on in the text, Aristotle argues that the highest form of knowledge must be independent from external conditions, and that the most perfect knowledge-wisdom-is knowledge for its own sake. In Aristotle's hierarchy, theoretical disciplines (theôrêtikon) were more wise than productive (poiêtikon) ones. ${ }^{14}$

When Aristotle refers to usefulness and necessity in the passage above, he evokes a range of meanings of these terms that refers to want and limitation imposed by the external conditions. ${ }^{15} \mathrm{He}$ views useful knowledge that responds to the necessities of life as unduly influenced by pressures from material conditions and he suggests that whoever is interested in useful knowledge is not free of worldly pressures himself. Because Hero justifies his treatises as useful, he has to challenge Aristotle's downgrading of useful knowledge to avoid being categorized as a practitioner of a lower from of knowledge. To do that, Hero needs to redefine the boundary by means of which Aristotle and other philosophical authors excluded mechanics and useful knowledge. Hero needs to escape from the association of useful knowledge with lowly craftsmanship and manual work.

Turning to Hero's texts, we get a different presentation of useful knowledge. In the introductions to the Pneumatics and Catoptrics Hero includes both provision for necessary needs and wonder-making as applications of mechanical knowledge. In the Pneumatics he states, for instance, how the principles of pneumatics cater for both needs and wonder:

For through the combination of air, fire, water and earth and combining three or four principles, varied (poikilai) arrangements can be actualized; these on the one hand provide the most necessary needs (anankaiotatai chreiai) of this life and, on the other, display some stunning wonder (ekplêktikos thaumasmos). ${ }^{16}$

Hero thus gives pneumatics a double function: it both provides for necessary needs and it generates wonder. Similarly in the introduction to the Catoptrics Hero emphasizes that the subject of catoptrics is a source both of useful devices and of devices designed to create wonder:

For catoptrics appears to be not just useful (utilis) for sights, but also for necessary uses (opportunitates necessariae). Who would not find it useful (utilis) to see the people living opposite, if they happen to be in the street, how many they are and

\footnotetext{
${ }^{14}$ Aristotle divides knowledge into three categories: theoretical knowledge that deals with understanding (theôrêtikon), such as mathematics, physics and metaphysics; practical knowledge that deals with action (praktikon), such as ethics and politics; and productive knowledge that deals with making things (poiêtikon), such as poetry and carpentry (see for example the Metaphysics, VI.1, 1025b19-1026a7; XI.7, 1064a1-28).

15 Aristotle employed the term 'necessity' in many other ways; ten distinct ones are recorded by Sorabji (1980), p. 222.

16 Pneumatics, 2.18-20.
} 
what they are doing? And who would not find it wondrous (mirabilis) to tell the hour night and day from figures appearing in a mirror ...., [and] who would also not find it wondrous (mirabilis) not to see oneself or anyone else in a mirror, but only whatever is chosen for it. ${ }^{17}$

How should we understand this twofold purpose of usefulness and wonder? We can begin by considering the examples of useful and wondrous devices that Hero offers in the passage from the Catoptrics just cited. Hero asks rhetorically, who would not find a given application 'useful', and who would not find a given application 'wondrous'? As 'useful' he characterizes a street-mirror that makes it possible to see what the neighbours are doing, and as 'wondrous' a clock that shows the time by displaying a new figure every hour and a mirror that shows a chosen image rather than one's own reflection. But the distinction between the useful and the wondrous as exemplified by these devices is far from obvious. Indeed the clock could equally well be characterized as 'useful' and the street-mirror as 'wondrous'. Both devices simultaneously provide an entertaining spectacle and serve a useful function. Therefore the function of the examples is not to distinguish between useful and wondrous devices, but rather to emphasize the scope of the needs covered in the treatise. The two categories utility and wonder do not refer to two separate needs, but rather to two aspects of catoptrics. ${ }^{18}$

A similar impression is given by the selection of devices described in the Pneumatics. Many of the devices have both practical and wondrous functions. For instance Hero describes an array of novelty devices for pouring and mixing wine at banquets. While these serve a practical purpose, they also generate surprise and wonder. One device serves wine either mixed with water or unmixed, but it can also serve straight water 'for those that we wish to jest with'. ${ }^{19}$ Likewise a device that opens a temple door when a fire is lit on an altar is at once useful and surprising. Even devices such as Hero's water-pump may have been employed to create wonder. Archaeological evidence exists not just for water-pumps that could be used as fire extinguishers or water pumps, but also for miniature models that may have been used for demonstrating the principle of the pump or for squirting perfume at symposia. ${ }^{20}$ Moving to another treatise, the combination of use and wonder is perhaps best illustrated by some of the lifting devices described in the Mechanics. The baroulkos-a mechanical contrivance based on geared wheels-is useful because it can lift heavy loads, but it is simultaneously wondrous because it allows a single man to lift two hundred times more than he would be able to unaided. ${ }^{21}$

Hero's presentation of mechanics as applicable both for making wonders and for necessary uses recurs in later accounts of mechanics. One such is found in the 4th

\footnotetext{
17 Catoptrics, 318.17-24.

18 The double aim of mechanics, necessity and wonder, is also noted in Lloyd (1973), p. 93; Cambiano (1994), pp. 617-621; and Cuomo (2000), pp. 103-104.

19 Pneumatics, 70.4-6.

20 Schürmann (1991), p. 108, and Oleson (1984), p. 324.

21 The baroulkos is described in the Mechanics, I.1; and in the Dioptra, 306.22-312.22.
} 
century mathematician Pappus of Alexandria's Collection, which includes a book on mechanics. Here, Pappus lists the different activities of mechanicians: they provided for the 'uses of life' by making lifting machines and war-engines, and they were also wonder-makers as exemplified by Hero's Automaton-construction and Pneumatics. ${ }^{22}$ Pappus thus presents wonder-making as an integral part of mechanics and he takes Hero to be a representative for this aspect of mechanics.

Pappus' account, however, makes it clear that wonder-making is not only about show-business; Archimedes' On floating bodies is listed as another example of wonder-making and this is not crowd-pleasing material! Pappus' inclusion of Archimedes' work reveals that wonder-making has an intellectual component- that of offering surprising insights in addition to staging wonders. Going back to Hero we find that he also uses the category of wonder to refer to intellectual surprise. In the Mechanics book II, Hero treats the five simple machines for lifting weights (the windlass, the lever, the pulley, the wedge and the screw) and after explaining how they work and describing various fancy combinations of them he concludes that

. . we will wonder at things which, when we have proved them, are contrary of what is known to us. The beginning for the things we are going to study, we derive from what is clear to us. But the things, the causes of which we can talk about after the objects that are most clear, will increase our wonder even more when we see that the things that we apply are contrary to what we became accustomed to and what we hold for certain. ${ }^{23}$

Thus, according to Hero, we wonder when we find unexpected causes behind wellknown phenomena. Wonder is induced by learning about mechanics as well as by spectacular mechanical devices.

A closer look at Hero's mechanical devices confirms that Hero's notion of utility has a theoretical component. While archaeological evidence shows that some of Hero's devices were in use, others were probably not feasible. The baroulkos (geared wheels) mentioned above could, for instance, not be used for heavy loads as it was impossible to make the cogs simultaneously both strong and sufficiently precise. ${ }^{24}$ The device has therefore been regarded as an illustration of the principle of gears rather than a description of a real device. Interestingly, however, Hero takes the resistance of the wheels into account when he estimates how much the baroulkos can lift. This has led some scholars to reject the idea that it was merely a hypothetical device. ${ }^{25}$ But, as we shall see in the following, practical considerations in the description of a device are no guarantee that the device was built or used. Hero often

\footnotetext{
${ }^{22}$ Pappus, Collection, book VIII, 1022.1-1028.3. Proclus, Commentary on the first book of Euclid's Elements, 41.3-42.8, also includes wonder-making under mechanics.

23 Mechanics, II.33.

24 There are examples of geared cog-wheels in astronomical devices, such as the Antikythera machine, but these carried no weight. Cog-wheels were used to carry weight in water-mills, but these were too coarse to make the baroulkos work. See Drachmann (1963), p. 32, and Humphrey et al. (1998), p. 52.

25 Landels (1978), p. 88. Hero considers the resistance of the gears at Mechanics, I.1.
} 
includes practical advice in the descriptions of devices that certainly had no practical use. He states, for instance, that a good, firm support is necessary for a lifting machine that combines a windlass, a screw, five pulleys and a lever, and he thereby indicates that one might actually want to build this unwieldy apparatus (see Fig. 1). But this device was not for practical use. Its role was to demonstrate the possibilities of mechanics and to give an example of how to calculate the lifting power of a complex device. Hero even discounts his result because it does not include friction and he thereby confirms that the point of the exercise is the number crunching rather than the practical virtues of the device. It follows that we cannot take for granted that Hero's references to the utility of mechanics correspond to our own category of utility. Hero employs utility as a header for all his activities, but modifies the concept in the process. The uses to which Hero refers include not only practical utility, but also more general applications of mechanical knowledge and expertise such as solving theoretical problems. ${ }^{26}$

We have now seen how Hero shows that wonder forms a continuum with utility, and that wonder and utility cannot be meaningfully separated. By associating utility with wonder, the range of uses is broadened beyond fulfilling necessary needs, which were thought, by Aristotle and others, to restrict the freedom of the mind. Moreover,

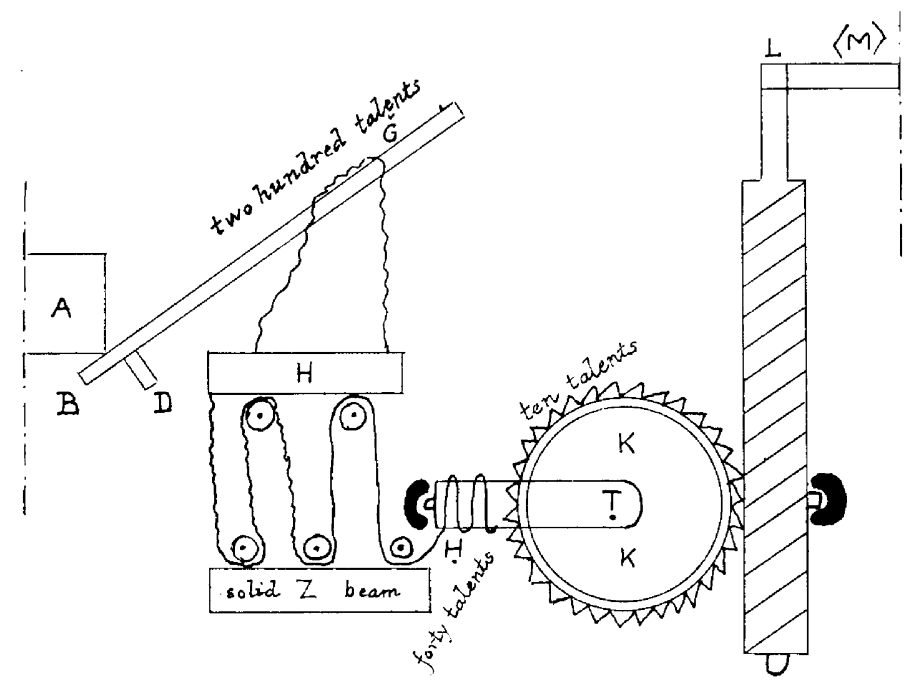

Fig. 1. This lifting device from the Mechanics, II.29, combines a windlass, a screw, five pulleys, and a lever (hand-drawn copy of the manuscript illustration from Drachmann (1963), p. 90).

\footnotetext{
26 There is evidence in Pappus that Hero was viewed as combining practical and theoretical aspects in his mechanics. 'The mechanicians around Hero' Pappus recounts 'say that there are a rational and a manual part of mechanics'; and he adds that theoretical mechanics deals with geometry and physical theory, whereas the manual part includes metal work, carpentry and painting. Pappus, Collection, $1022.13-15$.
} 
both the wonders and uses of mechanics have an intellectual aspect, and mechanics is thus elevated above simple manual work.

\section{Wonder and perception}

In this section I shall consider how wonder is also intertwined with Hero's account of perception and the epistemological status of mechanics; and how the mechanical spectacles support his theoretical claims about the constitution of matter.

Beginning with the spectacles, Hero writes in the introduction to the Automatonconstruction that the study of automata is worthwhile because of the craftsmanship involved and because it produces stunning spectacles.

The subject of Automaton-construction has been considered by our predecessors worthy of acceptance, both because of the variety (poikilos) in its craftsmanship (dêmiourgia) and because of the stunning (ekplektos) character of the spectacles (theoria). ${ }^{27}$

Following this statement Hero lists some of the effects he can produce in automatic theatres, for example lifelike movement and noise, a blazing fire that appears inside the theatre, and a figure that appears from nowhere. A main component in the 'stunning' character of these spectacles is that the cause of the spectacle is hidden: Hero hides the mechanisms that produce the effects. When a figure appears or disappears it creates surprise because the viewer cannot see from where it comes or to where it disappears, and in the same way life-like movements and sounds are produced with no visible mechanism or interference from humans. To exclude the possibility of human intervention, Hero even stipulates a maximum size for the automatic theatres in order that the audience does not suspect that there is a person inside the theatre pulling the strings. ${ }^{28}$ Hero, in fact, gives advice throughout the Automatonconstruction, Pneumatics, and Catoptrics on how to hide (kryptô) the mechanisms that produce the effects from the viewers, so that the audience cannot see the causes of the spectacles. ${ }^{29}$ By hiding mechanisms and pre-empting the spectators' suspicions, Hero creates a boundary between the unknowing spectator and the knowing mechanician. He thereby places the mechanician in an epistemically superior position because he can see the causes of the movements and the spectator cannot. This boundary is also implied in the descriptions of many of Hero's devices. When Hero, for instance, describes an automaton in the Pneumatics, he first describes the spectator's experience. There is a figurine of Hercules, a snake and an apple: when the

\footnotetext{
${ }^{27}$ Automaton-construction, 338.2-6. Translation in Murphy (1994) with my modifications.

28 Automaton-construction, 354.3-7.

${ }^{29}$ Objects or mechanisms that reveal the working behind the performance are 'hidden' (kryptô) (Automaton-construction, 434.8, 444.3; Pneumatics, 138.3, 148.9, 246.11); or made 'invisible' (aphanês) (Automaton-construction, 386.16, 396.8-9, 18, 416.8 etc.); or placed so they will not be seen (Catoptrics, 360.16-17).
} 
apple is lifted, Hercules fires his arrow towards the snake, which hisses in response (see Fig. 2). Only after this initial description of the spectacle does Hero reveal how the mechanism hidden in a box under the figurine works. The two separate descriptions of the spectacle and its causes reflect the difference between the mechanician and the audience. Only the mechanician-and reader of Hero's treatises-knows the hidden causes behind the show.

In the introduction to the Pneumatics Hero points to another significant aspect of perception. He argues that perceptibles provide the most reliable way of demonstrating theories of natural phenomena, and that demonstrations based on perceptibles are more reliable than demonstrations based on rational argument, logos. He writes,

For those who assert that there is absolutely no void, it suffices to invent lots of arguments and perhaps they seem more plausible (pithanôterous) with the abstract argument (logos), because no perceptible demonstration (aisthêtikê apodeixis) is available. But if it is shown on the basis of phenomena and by what falls under perception that continuous void is against nature, yet can be produced, ... then those who bring forward plausible arguments (pithanoi logoi) will not be able to escape through the back door. ${ }^{30}$

In this quote we are introduced to two methods of demonstration and if we look back to the opening of the Pneumatics we can identify the proponents of these two approaches. In the first couple of lines of the Pneumatics Hero notes that two groups

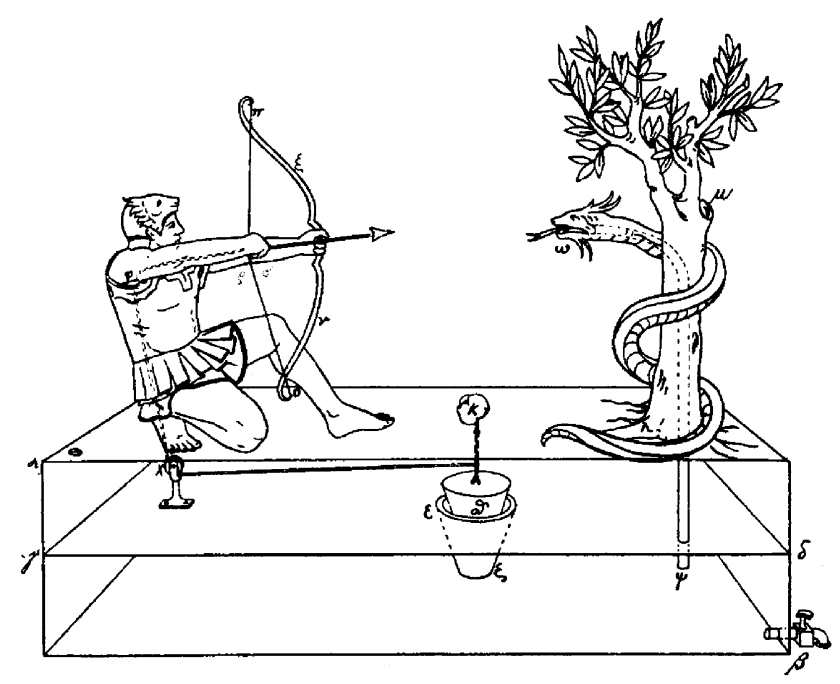

Fig. 2. Automaton featuring Hercules and a snake (from Pneumatics, p. 189; used with the permission of K. G. Saur).

\footnotetext{
${ }^{30}$ Pneumatics, 16.16-26.
} 
of people have worked on pneumatics - the mechanicians and the philosophers. The philosophers approached the subject with arguments (logikos), while the mechanicians produced perceptibles. ${ }^{31}$ Hence those in the quote above who use abstract arguments can be identified as the philosophers, whereas the demonstration based on perceptibles is associated with mechanics. Hero associates himself with the mechanicians because it is his own theory of the void that is demonstrated by perceptibles. So when Hero critically compares abstract arguments with demonstrations based on perceptibles, he simultaneously criticises the philosophical method and promotes the mechanical method.

The philosophical method is further characterized by Hero's use of the term 'plausible' (pithanos) to refer to the philosophers' arguments. This term also means 'calculated to persuade' and was often used about popular speakers, such as Sophists who gave public displays of their rhetorical skills, and whose popularity was on the increase in Hero's period. ${ }^{32}$ By this choice of term Hero indicates that philosophical arguments are closely related to rhetoric. In the context of demonstrating knowledge it is damning to be grouped with popular speakers because rhetoricians were (in)famous for the ability to make any viewpoint plausible to an audience; moreover rhetoricians aimed solely at convincing a particular audience, rather than at generating knowledge. The sinister nature of the association to rhetoric is further strengthened by Hero's remark that the philosophers' arguments will not allow them to 'escape through the back door' or 'find a loop-hole'. ${ }^{33}$

When Hero describes his own practice he uses the term 'demonstration' (apodeixis). This term was usually employed to refer to strong and rigorous forms of demonstration, such as deductive geometrical proofs or Aristotle's syllogisms. Through the work of Euclid and later Archimedes, geometrical demonstrations acquired prestige as a strict and highly persuasive form of argument. Philosophers also invested the term with high epistemic status and proposed modes of rigorous demonstration that purported to establish philosophy as a privileged form of knowledge that could be distinguished from knowledge that was merely plausible. Hence Hero's use of this term for demonstrations based on perceptibles in the Pneumatics is equivalent to a claim that perceptibles provide the most reliable way to establish secure knowledge.

Following the passage on demonstration cited above, Hero describes a demonstration of his theory of the void. He begins with a detailed account of how to construct a device consisting of an airtight metal ball with a pipe inserted at the top. We are given both the measures of the device and instructions for making the opening

\footnotetext{
31 Pneumatics, 2.4-7.

32 The increased popularity of Greek orators in Hero's period has sometimes been identified as part of the so-called Second Sophistic. This cultural movement spanned the period AD 50-250 and was characterized by an increased interest in Greek history, language and oratory. Whether or not such a movement can be properly discerned is debated, but the prominence of public declamations that drew large audiences is undisputed. Another feature worth noting is that many Sophists had close links to philosophical schools. See for instance Bowersock (1969); Anderson (1993); and Swain (1996).

33 Alternative renderings of Pneumatics, 16.24-26.
} 
around the pipe airtight with drips of tin, and Hero thus shows off his technical knowledge. At this stage the reader already knows that air, according to Hero's theory, consists of particles interspersed with small pockets of void; when a sample of air is compressed the pockets of void diminish, and when it is rarefied they expand. Hero now shows that the air inside the metal sphere can be rarefied by sucking air out through the pipe, and compressed by blowing extra air in through the pipe. On the basis of this performance Hero argues that it is demonstrated that air contains small pockets of void.

This demonstration is, however, problematic because the compression and expansion of air, contrary to what Hero purports, could easily be explained by the philosophers he challenges. The philosophers who argued against the existence of void, such as Aristotle and the Stoics, explained compressions and rarefaction of air in other ways. Aristotle, for instance, argues that air has the potential to expand and to compress, and thus avoids having to refer to any form of void. ${ }^{34}$ The strength of Hero's demonstration lies therefore not primarily in its power to reject rival theories, but rather in acting as a showcase for Hero's skill at producing and controlling physical phenomena.

When Hero sets out the demonstration he conjures up the image of an attending audience. 'Let us see what happens!' he exclaims before blowing air into the sphere and thus urges the reader to act as a perceiving audience. ${ }^{35}$ Hero creates a sense of immediacy by noting that the air blown into the sphere comes out with a 'loud noise' and by references to the demonstrator's body. He explains, for instance, that the person blowing into the vessel must 'immediately bring their hand up near their mouth and cover the pipe with a finger' and, earlier in the introduction, he describes how a vessel with a thin neck will suck itself onto one's lip when it has been emptied of air. ${ }^{36}$ Such physical descriptions create an impression that the demonstration is really taking place, and thereby add to its persuasiveness.

Hero's style of presentation parallels practices in other technical writers, particularly in medicine. ${ }^{37}$ Galen, who was a doctor and medical theorist in the second century $\mathrm{AD}$, describes, for instance, public stagings of anatomical dissections and vivisections, and he refers explicitly to the audience and their reactions. Like Hero, Galen details the technical skill and the materials involved in the performance and he lends immediacy to the description by referring to sense perceptions and the physical actions involved. For instance, in a demonstration of how the nerves of the thorax are connected to the voice, Galen ties a thread around a particular nerve bundle on a living animal and shows that it stops screaming when the thread is

\footnotetext{
${ }^{34}$ See, for example, Aristotle, Physics, IV.9, 217a11-217b26.

35 Pneumatics, 18.12.

36 Pneumatics, 20.13-15 and 8.17-21.

37 There are several links between mechanics and medicine. Hero is thought to have used a medical treatise as source for the Pneumatics, for he includes descriptions of medical instruments, a syringe and cupping-glasses. For similarities between medical and mechanical theories, see von Staden (1996), and Vegetti (1995).
} 
tightened and resumes screaming when it is loosened again. ${ }^{38} \mathrm{He}$ explains how to cut the animal, how to use a curved needle and which kind of thread to use, and he describes the audience as both 'stunned' and 'wondering' at the spectacle. ${ }^{39}$ Hero does not explicitly refer to wonder or an audience in his demonstration, but we saw earlier that Hero links pneumatics to wonder-making in the beginning of the Pneumatics, and in the opening of the Automaton-construction, which is quoted above, he states that the subject is admired for its craftsmanship and the 'stunning' character of its spectacles. Both Hero and Galen use the generation of wonder, the exhibition of technical skill, hands-on descriptions, and references to observables to create an image of expertise that supports their physical or anatomical theories.

Hero's and Galen's styles moreover bear similarities with that of popular speakers or rhetoricians ${ }^{40}$-interestingly the same people with whom Hero associated philosophers by calling their arguments merely 'plausible'. As stated above, public speakers or Sophists were famous for demonstrating their technical skills in display speeches in front of audiences. However, if we consider the vocabulary used to describe displays by public speakers, it is not in Hero's demonstrations of physical theories that we find the greatest similarities. These are found in the descriptions of the shows and displays, such as those on the automatic theatres. The term that Hero uses about a 'show' (epideixis) on an automaton is the same as that used in rhetorical contexts about 'display speeches', and the term used for the 'arrangement' (diathesis) of a scene on the theatre, is the same as that used about the 'delivery' of a speech in rhetoric. Hero also evaluates the set-pieces of his theatre according to whether they are 'plausible', which, as we saw earlier, is a term used about popular speakers. ${ }^{41}$

We have now gained an impression of Hero's complex use of rhetorical strategies and vocabulary. We have seen how Sophistic popular demonstrations provided Hero, and later Galen, with a good framework for exhibiting technical expertise, and how Hero employs many of these strategies in his demonstration with the spherical vessel. At the same time Hero separates himself from the shady reputation of rhetoric by associating it with philosophical arguments rather than with his own demonstrations. Thus Hero's own method of demonstration is presented as the most reliable method for establishing general knowledge. In contrast, the duplicity of rhetoric can be fruitfully related to the shows produced by automata. With the automaton the whole

\footnotetext{
${ }^{38}$ Galen, Anatomical procedures, VIII.4, in Kühn (1964-1965), vol. 2, 668-670.

${ }^{39}$ Galen, Anatomical procedures, VIII.4, in Kühn (1964-1965) vol. 2, 669.8-9: 'stunned (ekplêssô) spectators' and 'wondering (thaumassô) spectators', quoted from von Staden (1995), p. 59. Hero, Pneumatics, 2.19-20: 'display stunning wonder (ekplêktikos thaumasmos)'; and Automaton-construction, 338.4-6: 'the stunning (ekplêktikos) character of the spectacles'.

${ }^{40}$ The parallels between Galen's public dissections and the public declarations of orators and Sophists are studied in detail in von Staden (1995). Barton (1994, p. 147-49) emphasized the competitive aspect of both Sophistic displays and Galen's public dissections in her analysis of the rhetoric of knowledge and expertise in astrology, physiognomy and medicine.

${ }^{41}$ In Automaton-construction, 410.10, Hero states that 'the show (epideixis) is not unconvincing (pithanos)'; at 422.6 he stipulates that a group of background figures should be drawn standing in the 'most plausible (pithanotates) arrangement (diathesis)'. See also Automaton-construction 354.3 and Pneumatics, 174.8 .
} 
point is to create a convincing spectacle; the skill of the mechanician-like the skill of the orator-is demonstrated when he makes his audience wonder. In this way, Hero combines the orators' strategy for demonstrating technical expertise with his own claim that reliable knowledge can be established by demonstrations based on perceptibles.

Hero claims that demonstrations based on perceptibles are superior to philosophical arguments. However this standpoint was contested, for perception was frequently criticized by philosophers as unreliable. In the following, we shall see how Hero responds to the problems surrounding perception as a source of knowledge and how his wonder-making devices play a role in supporting the authority of sense perception.

In Hero's period one of the main reasons for holding perception to be suspect as a source of knowledge was the problem of perceptual illusion. The examples used by the Sceptics, such as Sextus Empiricus (second century AD), are famous: that a square tower looks round from a distance and that a straight stick looks bent when submerged into water. Moreover examples that are more directly relevant to Hero's work were used, such as that some mirrors show inverted or distorted images. ${ }^{42}$ Philosophers who argued in favour of some reliance on perception sought to deal with these problems. The Roman philosopher Lucretius (c.98-55 BC), for instance, considers in his De rerum natura a number of perceptual illusions, among them several effects created by mirrors that are similar to those described by Hero. ${ }^{43}$ These catoptrical illusions are explained in terms of a physical theory of perception, but the main reason why Lucretius includes the illusions is to illustrate the philosophical distinction between sense-impressions and the formation of beliefs about reality. ${ }^{44}$ This distinction is found in Epicurus' philosophy, which Lucretius followed closely. According to Epicurean epistemology immediate sense-impressions are reliable, but to gain knowledge about reality from perception one needs to distinguish between correct and incorrect inferences drawn from perceptual data; and to do that one requires knowledge of physical theory and philosophical reasoning. Interestingly Lucretius emphasizes that once we understand how these phenomena come about we should not wonder at them; philosophy eliminates the wonder caused by mirrors. ${ }^{45}$

Hero, like Lucretius, claims that knowledge can be derived from perceptibles, but he does not make a cognitive distinction between sense-impressions and beliefs, as many philosophers did. Rather than a distinction drawn with philosophical reasoning, Hero draws a line between the mechanician who can see behind the scenes and the audience from whom the mechanisms that govern the spectacles are hidden; between the mechanician who knows the causes and the audience that does not. What is seen

\footnotetext{
42 Sextus Empiricus, Outlines of Pyrrhonism, I.118, I.119, I.48.

${ }^{43}$ Lucretius, De rerum natura, 4.269-323. Both Hero and Lucretius refer to a mirror that inverts the image so the right side is shown on the right, and Lucretius describes how mirrors can reveal something that is inside a house-a contrivance similar to Hero's street-mirror, (Catoptrics XI and XVI).

44 Algra (1999).

${ }^{45}$ Lucretius, De rerum natura, VI.289-291: ‘ . . it is by no means right to wonder (miror) . . ’' why the image is seen behind the mirror; see also VI.256-258 and VI.462-466.
} 
on the stage of an automatic theatre does not count as perceptibles. In the Automataconstruction Hero consistently uses the term 'appearances' (phainomena) about what the spectator sees, or 'sense-impressions' (phantasiai) about illusions produced on stage, such as thunder. ${ }^{46}$ Perceptual illusions are a predicament of the audience, not of the mechanician.

Perception itself is, on the other hand, implied to be unproblematic in Hero's explanation of how vision works in the Catoptrics. According to Hero visual beams are emitted from the eyes, hit objects and are then reflected back to the eye. Hero compares visual beams to stones hurled against and reflected from hard surfaces. These beams travel in straight lines and Hero shows geometrically that they are reflected at equal angles. ${ }^{47}$ With this theory of perception Hero makes perception explicable in terms of mechanical knowledge, which combines practical knowledge, physical theory and geometry. Moreover, Hero shows that this theory allows him to control what is seen. By covering and uncovering the point on a mirror where the visual beam is reflected Hero makes an image disappear and reappear. ${ }^{48}$

By explaining and controlling vision in this way Hero makes visual perception explicable as a mechanical process. What we see is determined by the force of the visual beam, the hardness of the object, and the geometrical relation between the observer and the object. Understanding perception means that Hero can rely on perception in his demonstrations. He gets around the problem of perceptual illusions by creating illusory spectacles, with mirrors, for example. Where the philosophers have to explain how illusions occur, Hero shows how they can be produced. Where Lucretius emphasizes that mirrors should not make us wonder, Hero shows how we can make the audience wonder. Although Hero's devices do not in general produce the same illusions as the philosophers discussed and Hero did not construct his devices in direct response to the perceptual puzzles of philosophy, ${ }^{49}$ he was probably aware of the debates about perception. By constructing a boundary between the spectacle and the mechanism that controls it Hero is able to appropriate perception as a reliable basis of knowledge and to privilege the mechanician who understands the causes behind what is seen.

\section{Wonder and mythology}

The vocabulary used to describe wondrous devices has associations both with craftsmanship and skill, and with mythological embodiments of skill and inven-

\footnotetext{
${ }^{46}$ Hero uses different forms of the term 'appear' (phainô) eleven times on a single page in the text edition, when he describes one of the shows, Automaton-construction, 340. For the use of the term 'senseimpression' about illusions see Automaton-construction, 450.8, and Pneumatics, 136.13.

47 Catoptrics, 322.9-328.8.

48 Catoptrics, 330.4-22.

49 Lloyd (1991) argued that epistemological debates in philosophy did not affect the attitude to measurement in the 'exact sciences'. This conclusion does not, however, preclude that practitioners of the 'exact sciences' were aware of the philosophical debates.
} 
tiveness. Hero uses these associations to enhance his presentation of the wondrous effects produced by mechanical devices. As we shall see, the vocabulary chosen and the effects produced support each other in showing that craftsmanship and divine cunning coexist in mechanical skill (technê).

The term mechanics derives from mechanê, which means 'crane', 'machine' or 'device'. This term, however, has a broader range of meanings similar to those of 'device' and can also mean 'contrivance' or 'wile'. In Hero's Mechanics the main concern is how to lift a heavy weight with a small power and he describes a number of cranes, presses and levers. These devices are, at the same time, 'contrivances' or 'wiles' that allow weights to be lifted against their natural inclination. Thus, Hero uses the whole range of the term: the mechanical device both lifts a weight and displays a trick.

The craftiness of mechanics is also reflected in the use of other terms. In the opening to Automaton-construction quoted at the beginning of the last section, Hero states that the subject of automaton-construction has been considered worthwhile because of its 'varied' or 'multifaceted' (poikilos) craftsmanship (dêmiourgia) and its stunning spectacles. Hero here refers explicitly to the craftsmanship involved in mechanics, and also maintains the link between craft and craftiness. The term poikilos - 'varied'-is not only used to refer to complex craftsmanship, such as woven cloth or wrought metalwork where it means 'many-coloured' or 'shimmering'; it also links craftsmanship to the creation of wonder and spectacles meaning 'changeful', 'artful' or 'wily'. 50

In general, the terms with which Hero describes the wonder of mechanics bear more than a passing resemblance to the semantic field that Detienne and Vernant mapped under the heading of 'cunning intelligence' (mêtis). ${ }^{51}$ In their examination of the role of mêtis in Greek culture they described it as a subversive form of intelligence that thrives and operates in changing and varied conditions; it differs from the theoretical knowledge characterized and promoted by philosophers, for it operates in practical contexts and takes the form of, for example, deception, experience or skill. It has divine manifestations in several of the gods, such as Athena, Hephaistos, Hermes and Zeus, as well as in other characters of wily intelligence such as Odysseus and Prometheus. Mêtis is also the kind of intelligence that governs the practical skills of the arts, from weaving and hunting to medicine and rhetoric. The terminology of cunning intelligence is highly relevant for Hero because it combines divine power with the skill of the craftsman. In fact the term mechanê is related to mêtis and is associated with many of the same skills and characters as cunning intelligence.

Prometheus is described as the originator of the arts or skills (technai) in Hesiod's Theogony and Ps-Aeschylus' Prometheus bound. Prometheus brought fire and the arts to mankind and his character embodies many of the features of mêtis and technê; he is cunning, resourceful and occupies a liminal position-in Prometheus' case

\footnotetext{
50 'Varied' 'poikilos' is used at Pneumatics, 2.18, 28.14, and Automaton-construction 338.4, 342.6, 404.15.

51 Detienne \& Vernant (1978).
} 
between Olympus and the human world. Prometheus and Odysseus were resourceful (polymechanôs) and never at a loss; Prometheus always found '. . . a way out of the inextricable (amêchanon)', ${ }^{52}$ and he is described as poikilos, that is 'artful' or 'wily'. ${ }^{33}$ Terms such as poikilos and mêchanê are, as we have seen, also employed by Hero and although he uses them to refer to aspects of mechanics, he exploits the mythical associations of these terms to emphasize the cunning and wondrous aspect of mechanics. When Prometheus listed the arts (technai) he brought to mankind, he held the listeners' attention with the words: 'Hear the rest and you will wonder more at the arts and ways I devised'. ${ }^{54}$ Thus the technai, and thereby the craftsmanship of mechanics, are related to wonder and Hero brings out this aspect very clearly in his terminology.

Like Hero's spectacles, cunning intelligence involves an element of deceit where appearance and reality do not match. When Hero advises how to hide parts of the mechanism, in his automata for example, he separates appearance and reality, and thereby uses a form of cunning intelligence to deceive his audience by manipulating their perceptions. Likewise when Hero allows a small power to lift a large weight, he displays a trick that seems to overturn the natural order through the application of cunning intelligence.

The point of comparing Hero's presentation of mechanics to the semantic field of cunning intelligence or mêtis as mapped by Detienne and Vernant is to show that Hero's wondrous effects are not to be regarded merely as entertainment. In his displays, Hero exercises a recognisable and powerful form of knowledge and expertise. Thus Hero not only shows that mechanics provides an alternative to philosophy with regards to gaining knowledge about natural phenomena, he also evokes the special powers of practical and crafty knowledge.

The association to cunning and practical intelligence established by Hero's terminology is reinforced by the spectacles Hero describes, many of which are connected to mythology and religion. The displays designed for the automatic theatres are a case in point. One theatre features an adaptation of the story of Nauplius, which derives from the same body of myths that form the basis for the Iliad and the Odyssey. The Greeks are on their way home from the battle at Troy, but Nauplius causes the Greeks' ships to wreck by lighting false beacons from the coast. Ajax, the leader of the Greeks, is then killed by a thunderbolt from Athena. Hero does not offer much of a storyline, but merely describes the scenes for the displays on the theatre. The story is presupposed to be known by the reader or the audience.

Hero's first scene features a group of figures, representing the Greeks, repairing their ships. They use hammers, saws and axes as well as a bow-drill and augers. This scene does not add much to the narrative, but it is nevertheless worked out in much detail. By displaying this elaborate scene Hero demonstrates his technical ability as a mechanician while simultaneously displaying mythological heroes

\footnotetext{
52 [Aeschylus], Prometheus bound, 59.

53 [Aeschylus], Prometheus bound, 308; Hesiod, Theogony, 511.

54 [Aeschylus], Prometheus bound, 476-477.
} 
engaged in manual work and thereby highlighting the mythological sanctioning of craftsmanship.

The story of Hero's show may have been based on the tragedy by Sophocles, Nauplius pyrkaeus, from which only a few fragments are preserved. ${ }^{55}$ The one, longer fragment preserved seems to indicate that the story was fitting for an automatic theatre. The fragment describes Nauplius' son Palamedes, whose death Nauplius is revenging when he causes the Greeks' shipwreck and who invented a variety of arts.

This man Palamedes devised a fortification wall for the Argive army; the inventions of weight, numbers and measures; invented the battle array and interpretation of heavenly signs. He was also the first to find how to count from one to ten, and in turn from ten to fifty and to a thousand; he brought to light the fiery beacons of the army and revealed things not known before. ${ }^{56}$

Thus, although Palamedes does not figure in Hero's show, the story of Nauplius may have been associated with the praise of the inventions of the man around whose death the tragedy turns. The connection to the mythological origins of the arts was then underscored by the image of the Greek heroes engaged in repairing their ships. References to the power of the arts are also found in other tragedies and the performance of a tragedy in itself constitutes a spectacle, which Hero recreates on his automatic theatre. ${ }^{57}$

Hero's other automatic theatre simply features a tableau, in which Nike and Dionysus are shown with a group of dancing Maenads accompanied by cymbals and drums. A fire blazes up on an altar and Dionysus' thyrsus ${ }^{58}$ sprays milk or water while wine is poured from a cup onto a panther lying at his feet (see Fig. 3). The religious flavour of the drink sacrifice is reinforced by Hero referring to the theatre as a 'shrine or altar', 59 and a comparison of Hero's show to religious processions confirms the connection.

Athenaeus (fl. AD 200) includes in his Deipnosophistai an account of a Grand Procession, which he states took place under the auspices of Ptolemy II Philadelphus (308-246 BC). Athenaeus' description is thought to rely on an earlier account describing the wonders of Alexandria, and the account does indeed describe an amazingly ostentatious procession featuring endless riches and constituting an opulent

\footnotetext{
55 This view is supported by Prou (1881), and Weil (1882).

56 Sophocles, Nauplius, fragment 432. Translation in Humphrey et al. (1998), no. 1.22. The Greek text in Radt (1977), Vol. 4, is controversial, but the praise of the technical inventions is clear. The fragment stems from a third century AD commentary on Aratus' Phainomena by Achilles Tatius; interestingly it is quoted after an excerpt from Prometheus bound, Maass (1898), p. 27.

57 In Sophocles' Antigone, 332ff, the choir recounts the development of the arts from navigation to politics.

58 A thyrsus was a wand wreathed in ivy and wine leaves.

59 Automaton-construction, 338.10.
} 


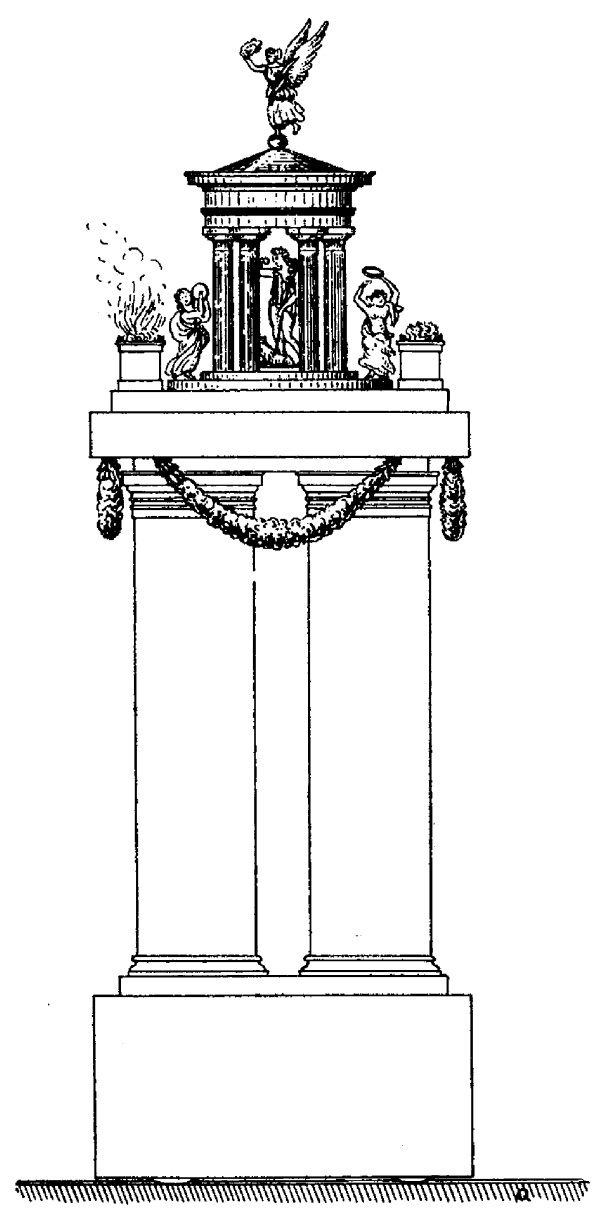

Fig. 3. Automatic theatre featuring Dionysus and Nike (from Automaton-construction, p. 351; used with the permission of K. G. Saur).

display of power. ${ }^{60}$ Despite the distance in time, the show on Hero's automatic theatre has many features in common with the displays of the procession. The best known display is the statue of the otherwise unknown goddess Nysa, which could stand up and sit down automatically and which sprayed libations of milk and water. ${ }^{61}$ So automata were used in actual religious displays. Moreover, Athenaeus describes an

\footnotetext{
${ }^{60}$ The fifth book of Athenaenus' Deipnosophistai gives a detailed account of the Grand Procession of Ptolemy Philadelphus. Rice (1983) gives a translation and a detailed commentary. The text is an excerpt from a larger work by Kallixeinos called About Alexandria. Little is known of this work, but Rice notes that the description of the Ptolemeia procession was the culmination of a catalogue of wonders.

${ }^{61}$ Athenaeus, Deipnosophistai, V 197c-203b; translation and commentary in Rice (1983). Rice suggests with Fraser (1972) that the statue was the work of the mechanical author Ctesibius on whose work Hero may have drawn.
} 
array of tableaux in which Dionysus played the central role, for instance in a series of representations of Dionysus' life. Among other things these featured a symbolic 'army of Dionysus' consisting of dancing Maenads and Satyrs. ${ }^{62}$ Like the procession, Hero's theatre also has Dionysus as its central character, libations of milk or water, and dancing maenads. Hero's description of the theatre may thereby be seen as providing the know-how behind the massive display of religious and secular power featured by the Grand Procession.

Hero also appears to have taken inspiration from religious practices for other of his devices; he describes several devices which are explicitly stated to be for use in temples such as a device that makes a bird sing when worshippers turn a bronze wheel or a mirror that shows the image of a goddess. ${ }^{63}$ Moreover many devices, both in the Pneumatics and Catoptrics, feature images of divine and mythological characters such as Athena, Zeus, Heracles and Pan as well as satyrs and a triton. ${ }^{64}$

The link between Hero's shows and devices, and the divine and mythology is, I believe, central to Hero's presentation of mechanics. It recaptures the idea that the crafts are closely connected to divine powers. Thereby the practical know-how of mechanics is given a mythological ancestry and is elevated from its lowly tier in the hierarchy of knowledge. Wonder associated with myths is translated into the wonder sparked by the exhibition of mechanical skill and expertise. More pragmatically Hero invests mechanics with the power associated with religious processions and displays for banquets by explaining how such spectacles can be understood. The fact that many of Hero's devices are for use in temples or at banquets also indicates that Hero targeted readers who were associated with the elite and who displayed their wealth by putting on lavish shows. ${ }^{65}$

\section{Conclusion: philosophical wonder}

I shall now return to Aristotle's Metaphysics, which I discussed in the beginning of this paper. We saw how Aristotle placed the arts and useful knowledge below philosophy, which he took to be the highest form of knowledge. Further on in the Metaphysics, Aristotle describes how philosophy originated. In contrast to the arts, which came about in order to satisfy needs, philosophy was motivated by-lo and behold-wonder:

\footnotetext{
${ }^{62}$ The procession of Dionysus makes up two thirds of the procession as a whole. Athenaeus, Deipnosophistai, V.197e-201e.

63 Pneumatics, 98.4-100.15 (I.17), 148.2-150.12 (I.32), 174.11-182.6 (I.38-39), 299.7-302.3 (II.32); Catoptrics, 358.1-354.4 (18).

${ }^{64}$ Pneumatics, 186.8 (Heracles), 140.8, 144.9, 330.6 (Pan), 170.2; 242.10, 320.8 (Triton); Catoptrics 342.10 (Athena and Zeus).

65 Farrington (1950), pp. 199-200, called science the 'handmaid of religion', but as many of the devices were probably not built it is more plausible that Hero drew on the status of religion, than that religion 'used' science.
} 
That [philosophy] is not a science of production is clear even from the history of the earliest philosophers. For it is through wonder (thaumazein) that men now begin and originally began to philosophize; wondering (thaumazô) originally at the obvious perplexities, and then advanced little by little and stated difficulties about the greater matters too, e.g. about the phenomena of the moon and those of the sun and the stars and about the genesis of the universe. And a man who is puzzled and wonders (thaumazô) thinks himself ignorant (when even the mythlover is in a sense a philosopher, for myth is composed of wonders (thaumasios)); therefore since they philosophized in order to escape from ignorance, evidently they were pursuing science in order to know, and not for any for the sake of knowledge, and not for any utilitarian end (chrêsis). ${ }^{66}$

In this passage Aristotle appropriates wonder and mythology as starting points for philosophical inquiry. In doing so he may have followed Plato who takes wonder to be the beginning of philosophy in his Theaetetus. ${ }^{67}$ Philosophy thus acquires the divine ancestry from the arts, and by equating wonder with simple ignorance, Aristotle separates wonder from craftsmanship and utility. Instead Aristotle uses wonder to present philosophy as knowledge for knowledge's sake because it springs from wonder and ignorance rather than from need. Aristotle moves on to separate the pursuit of knowledge further from utility by explaining that philosophical speculation began when all necessities were supplied. ${ }^{68}$

Further on in the text Aristotle explains the relation between wonder and knowledge:

Yet the acquisition of [this knowledge] must in a sense end in something which is the opposite of our original inquiries. For all men begin, as we said, by wondering (thaumazô) that the matter is so (as in the case of wondrous (thaumatos) automata or the solstices, or the incommensurability of the diagonal of a square with the side; for it seems wonderful (thaumatos) to all men who have not yet considered the explanation that there is a thing which cannot be measured even by the smallest unit). But we must end in the contrary and better state . . . for the geometer would wonder (thaumazô) at nothing so much as if the diagonal turned out to be commensurable. ${ }^{69}$

Acquiring knowledge involves, according to Aristotle, an inversion of the initial state of wondering. At first one is ignorant and wonders at how things are. But after

\footnotetext{
66 Aristoteles, Metaphysics I, 982b11-23. Translation by Ross in Barnes (1984) with my modifications.

${ }^{67}$ Theaetetus, 155d2-5. Socrates states: 'For this is an experience which is characteristic of a philosopher, this wondering: this is where philosophy begins and nowhere else. And the man who made Iris the child of Thaumas was perhaps not a bad genealogist'. The latter part refers to Hesiod's Theogony, 256; 'Thaumas' means wonder and Iris, the messenger of the gods, is the rainbow which passes between the earth and heaven. Translation and note is by Levett, revised in Burnyeat (1990).

68 Aristotle, Metaphysics I, 982b23-25.

69 Aristotle, Metaphysics I, 983a11-21. Translation by Ross in Barnes (1984) with my modifications.
} 
understanding the causes behind the phenomena, it would surprise if things were not so. Wonder thus derives from an epistemic barrier between being able to explain incommensurable magnitudes or automata, and not being able to. Hero plays on this contrast too when he first describes what the spectator sees, and then how the mechanism works. In fact all Hero's descriptions of automata and other spectacles can be understood as demonstrations of the epistemic superiority of the mechanician, who understands the underlying mechanisms, over the unknowing audience who only experiences the spectacle itself.

As we have seen Hero responds to Aristotle's generally critical attitude to useful knowledge by re-appropriating the concept of wonder at a number of levels. First we saw how Hero eliminates the distinction between wonder and utility, and makes both products of mechanics. He thereby removes mechanics from the negative associations of practical utility because wonder was linked with inquiry, knowledge and myth by philosophers such as Plato and Aristotle. Moreover, Hero gives utility and wonder an intellectual aspect by moving beyond feasibility in his descriptions of devices. Second, Hero uses the spectacles generated by his devices to lend immediacy to his demonstrations and give them the direct appeal of a rhetorical display. He claims that his method of demonstration-through perception-is superior to philosophical arguments and circumvents the problems associated with perception by explaining and controlling visual perception and the production of illusory spectacles. Last, we saw how Hero connected mythology with craftsmanship, and how he designed mechanical devices for temples. In this way, he gave the mechanician's craftsmanship and expertise divine ancestry and authority.

Wonder is a key concept in the relations between practical and theoretical knowledge and between mechanics and philosophy, but these relations are not simple. Hero eliminates clear-cut distinctions between theory and practice, between wonder and necessary needs, and between philosophy and mechanics. He assigns to mechanical wonder-making the epistemic power that philosophers had previously associated with wisdom and reason.

\section{References}

Algra, K. (1999). Walking images: Epicurean catoptrics in Lucretius DRN IV 318-323. Elenchos, 20, 359-379.

Anderson, G. (1993). The Second Sophistic: A cultural phenomenon in the Roman Empire. London: Routledge.

Barnes, J. (Ed.). (1984). The complete works of Aristotle: The revised Oxford translation. Princeton: Princeton University Press.

Barton, T. (1994). Power and knowledge. Astrology, physiognomics, and medicine under the Roman Empire. Ann Arbor: The University of Michigan Press.

Berryman, S. (1997). Horror Vacui in the third century BC: When is a theory not a theory? In R. Sorabji (Ed.), Aristotle and after (pp. 147-157). London: Institute of Classical Studies.

Bowersock, G. W. (1969). Greek sophists in the Roman Empire. Oxford: Oxford University Press.

Brumbaugh, R. S. (1966). Ancient Greek gadgets and machines. New York: Thomas Y. Cromwell Company.

Brunet, P., \& Miele, A. (1935). Histoire des sciences: Antiquité. Paris: Payot. 
Burnyeat, M. (1990). Plato's Theaetetus (revised with commentary by M. J. Levett). Indianapolis: Hackett Publishing Company.

Cambiano, G. (1994). Automaton. Studi Storici, 35, 613-633.

Cuomo, S. (2000). Pappus of Alexandria and the mathematics of late Antiquity. Cambridge: Cambridge University Press.

Daston, L., \& Park, K. (1998). Wonders and the order of nature. New York: Zone, 1150-1750.

Detienne, M. \& Vernant, J.-P. (1978). Cunning intelligence in Greek culture and society (J. Lloyd, Trans.). Hassocks: Harvester Press.

Diels, H. (1893). Über das physikalische System des Straton. Sitzungsberichte der kgl. preussischen Akademie der Wissenschaften, 9, 101-127.

Drachmann, A. G. (1948). Ktesibios, Philon and Heron: A study in ancient pneumatics. Copenhagen: Munksgaard.

Drachmann, A. G. (1963). The mechanical technology of Greek and Roman Antiquity: A study of the literary sources. Copenhagen: Munksgaard.

Farrington, B. (1950). Science in antiquity. London: Oxford University Press.

Finley, M. I. (1959). Technology in the ancient world. Economic History Review, 12, 120-125.

Fraser, P. M. (1972). Ptolemaic Alexandria (3 vols.). Oxford: Clarendon Press.

Furley, D. J. (1989). Strato's theory of the void. In Cosmic problems: Essays on Greek and Roman philosophy of nature (pp. 149-171). Cambridge: Cambridge University Press.

Gille, B. (1957). Machines. In C. Singer, E. J. Holmyard, \& A. R. Hall (Eds.), A history of technology. Oxford: Clarendon Press.

Green, P. (1990). Alexander to Actium. London: Thames and Hudson.

Hill, D. R. (1984). A history of engineering in classical and medieval times. London: Croom Helm.

Humphrey, J. W., Oleson, J. P., \& Sherwood, A. N. (Eds.). (1998). Greek and Roman technology. A sourcebook. London: Routledge.

Jones, A. (2001). Pseudo-Ptolemy De Speculis. SCIAMUS, 2, 145-186.

Kiechle, F. (1969). Sklavenarbeit und technischer Fortschritt im Römischen Reich. Wiesbaden: F. Steiner.

Klemm, F. (1954). Technik: Eine geschichte ihrer probleme. Freiburg: K. Alber.

Kühn, K. G. (Ed.) (1964-1965). Claudii Galeni Opera Omnia (22 vols.). Hildesheim: Georg Olms Verlagsbuchshandlung.

Landels, J. G. (1978). Engineering in the ancient world. London: Chatto \& Windus.

Lee, D. (1973). Science and Technology in the Greco-Roman world. Greece and Rome, 20, 65-70, 180-193.

Lehoux, D. (1999). All voids large and small, being a discussion of place and void in Strato of Lampsacus' matter theory. Apeiron, 32, 1-36.

Lloyd, G. E. R. (1973). Greek science after Aristotle. London: Norton.

Lloyd, G. E. R. (1991). Observational error in later Greek science. In Methods and problems in Greek science (pp. 299-332). Cambridge: Cambridge University Press.

Maass, E. (Ed.). (1898). Commentarium in Aratum Reliquiae. Berlin: Weidmann.

Marsden, E. W. (1971). Greek and Roman artillery: Technical treatises. Oxford: Clarendon Press.

Murphy, S. E. (1994). Heron of Alexandria's 'On Automata-Making'. History of Technology, 17, 1-44.

Neugebauer, O. (1938). Über eine Methode zur Distanzbestimmung Alexandria-Rom bei Heron. Det Kgl. Danske Videnskabernes Selskab. Historisk-filologiske Meddelelser, 26(2), 3-26.

Oleson, J. P. (1984). Greek and Roman mechanical water-lifting devices. The history of a technology. Toronto: University of Toronto Press.

Pleket, H. W. (1967). Technology and society in the Greco-Roman world. Acta Historica Neerlandia, 2 , $1-25$.

Pleket, H. W. (1973). Technology in the Greco-Roman world: A general report. T $\alpha \lambda \alpha \nu \tau \alpha, 5$, 6-47.

Prou, V. (1881). Les théâtres d'automates en Grèce au IIe siècle avant l'ère chrétienne d'après les

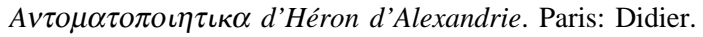

Radt, S. (Ed.). (1977). Tragicorum Graecorum Fragmenta (4 vols.). Göttingen: Vandenhoeck \& Ruprecht.

Reece, D. W. (1969). The technological weakness of the ancient world. Greece and Rome, 16, 32-47.

Rice, E. E. (1983). The grand procession of Ptolemy Philadelphus. Oxford: Oxford University Press. 
Ross, W. D. (1958). Aristotle's Metaphysics: A revised text with introduction and commentary. Oxford: Clarendon Press.

Schmidt, W., \& Nix, L., (Eds.). (1900). Heronis Alexandrini: Opera quae supersunt omnia, Vol. 2: Mechanica et catoptrica. Leipzig: Teubner.

Schmidt, W., Nix, L. L. M., Schöne, H., \& Heiberg, J. L. (Eds.). (1899-1914). Heronis Alexandrini Opera qvae svpersvnt omnia (5 vols.). Leipzig: Teubner.

Schürmann, A. (1991). Griechische Mekanik und antike Gesellschaft: Studien sur staatlichen Förderung einer technischen Wissenschaft. Stuttgart: Steiner.

Sorabji, R. (1980). Necessity, cause and blame. Perspectives on Aristotle's theory. London: Duckworth.

Staden von, H. (1989). Herophilus: The art of medicine in early Alexandria. Cambridge: Cambridge University Press.

Staden von, H. (1995). Anatomy as rhetoric: Galen on dissection and persuasion. Journal of the History of Medicine and Allied Sciences, 50, 47-66.

von Staden, H. (1996). Body and machine: Interactions between medicine, mechanics and philosophy in early Alexandria. In Alexandria and Alexandrianism (pp. 85-106). Malibu, CA: J Paul Getty Museum.

Swain, S. (1996). Hellenism and empire: Language, classicism, and power in the Greek world, AD 50250. Oxford: Clarendon Press.

Tybjerg, K. (2000). Doing philosophy with machines: Hero of Alexandria's rhetoric of mechanics in relation to the contemporary philosophy, Ph.D. thesis, University of Cambridge.

Vegetti, M. (1995). L'épistémologie d'Erasistrate et la technologie hellénistique. In P. J. v. d. Eijk, H. H. J. Horstmanshoff, \& P. H. Schrijvers (Eds.), Ancient medicine in its socio-cultural context (pp. 461-472). Amsterdam: Rodopi.

Vernant, J.-P. (1957). Remarques sur les formes et les limites de la pensée technique chez les Grecs. Revue d'histoire des science, 10, 205-225.

Weil, H. (1882). Les théâtres d'automates en Grèce au IIe siècle avant l'ère chretienne d'après les

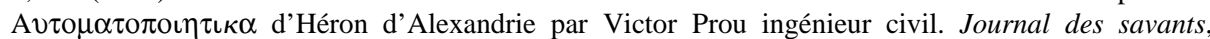
416-424.

White, K. D. (1984). Greek and Roman technology. London: Thames and Hudson.

Wikander, Ö. (1984). Exploitation of water-power or technological stagnation? A reappraisal of the productive forces in the Roman Empire. Lund: C. W. K. Gleerup. 